\title{
Analysis of Structure and Textures of Anhydrite Mineral in Gachsaran Formation in Gotvand Area, Iran
}

\author{
Maryam Marandi' ${ }^{1}$, Davood Jahani ${ }^{1}$, Ali Uromeihy ${ }^{2}$, Majid Karimpour Reihan ${ }^{3}$ \\ ${ }^{1}$ Department of Geology, North Tehran Branch, Islamic Azad University (IAU), Tehran, Iran \\ ${ }^{2}$ Department of Geology, Tarbiat Modares University, Tehran, Iran \\ ${ }^{3}$ Department of Geology, International Desert Research Center, University of Tehran, Tehran, Iran \\ Email: jahani_davood@yahoo.com
}

How to cite this paper: Marandi, M., Jahani, D., Uromeihy, A. and Reihan, M.K. (2017) Analysis of Structure and Textures of Anhydrite Mineral in Gachsaran Formation in Gotvand Area, Iran. Open Journal of Geology, 7, 1478-1493.

https://doi.org/10.4236/ojg.2017.710099

Received: August 23, 2017

Accepted: October 15, 2017

Published: October 18, 2017

Copyright $\odot 2017$ by authors and Scientific Research Publishing Inc. This work is licensed under the Creative Commons Attribution International License (CC BY 4.0).

http://creativecommons.org/licenses/by/4.0/

\begin{abstract}
Minerals are deposited when evaporation is greater than atmospheric precipitation. Calcium sulfates are one of the most important evaporative minerals which have been expanding over the past few years. In the formation of these minerals, various sedimentary and diagenetic processes play a role from shallow ridges to deep water. The research investigated the types of evaporative minerals (with an emphasis on anhydrite) in Gachsaran Formation in Gotvand dam range ( $25 \mathrm{~km}$ north of Shoushtar city). Investigating the thin sections of evaporative samples of this formation led to the identification of various anhydrite textures. Also, the existence of the main phases of calcium sulfate and $\mathrm{NaCl}$ by XRD analyses on a number of samples. The formation of anhydrite, gypsum and halite minerals in Gachsaran Formation in Lagoon and Sabkha environments was identified texture. The most important textures were laths anhydrite, nodule, isolated, radial anhydrite crystals, and porphyroblastic gypsum crystals, most of which are formed at the same stage of precipitation or in the early stages of diagenesis.
\end{abstract}

\section{Keywords}

Gachsaran Formation, Lower Miocene, Evaporation, Anhydrite

\section{Introduction}

Evaporatives include a wide range of chemical deposits which are resulted through evaporation of inspissated brines from or near the surface of the earth [1] [2]. Evaporatives are also formed in the form of crystalline growth, succes- 
sion, or cementitious in vaporous or non-evaporative host rocks. Limestone, dolomite and calcareous clays are the most common sediments with evaporatives [3] [4].

The main evaporative minerals include gypsum, anhydrite and halite. Most of the old evaporatives are mostly due to the increase in concentrations of saline waters with a source of seawater [5]. Geological evidence and present-day events show that two minerals of gypsum and anhydrite are deposited on the surface of the earth underwater (in shallow and deep water) and inland (in coastal and subaerial sabkhas) [6]. Gypsum formation occurs under low temperature-pressure conditions and low salinity levels. Anhydrite is also formed at higher temperature-pressure and higher salinity levels.

The presence of evaporative minerals in hydraulic structures such as dams can, in the long run, lead to the risk of water leakage from the reservoir of dams. Also, the presence of these minerals in the reservoir of dams, after damping the barrier influences the water quality of the dam. Therefore, there are always problems with numerous projects worldwide, due to the presence of soluble evaporative minerals and numerous studies have been carried out by researchers to evaluate potential hazards and to improve the hydraulic structures where evaporative deposits exist in their sites (in the place of the foundation and reservoir) [7] [8] [9] and [10]. Therefore, in these structures, it is necessary to determine the type of evaporative mineral and to know the characteristics and degree of their dissolution. The process of dissolving evaporative minerals in water plays a very important role in the evaluation of geochemical systems, and the type of evaporative minerals should be investigated to determine this process.

The aim of this study was to investigate the type of evaporative minerals and their structures and their texture in Gachsaran Formation at Gotvand dam site and their effect on this hydraulic structure.

\section{Geographical Location of the Region}

The boundary of the Gotvand dam (Figure 1), which is one of the major dams of Iran, is located on the Karun River, $378.3 \mathrm{~km}$, of the river estuary and $25 \mathrm{Km}$ north of Shoushtar city (Figure 2). The Gotvand dam reservoir as one of the water reservoirs in Iran, is surrounded by Gachsaran, Mishan, Aghajari, Lohbari and Bakhtiari formations, with a length of more than $90 \mathrm{~km}$.

Evaporative deposits of Gachsaran Formation with an approximate length of $2.5 \mathrm{~km}$ and within four kilometers of the axis of the dam and its upstream are composed of layers of marl, anhydrite and salt (Figure 3 ).

The study area is based on the map of structural divisions and expansion of Iranian sedimentary basins [11] folded in the Zagros area and is located in part of Zagros called Dezful Embayment, and has been generally covered with Fars group formations as well as Bakhtiari conglomerates and younger sediments.

In Dezful Embayment, sedimentation along with the development of folding in late Cenozoic, the has consisted Gachsaran formation on the Asmari Forma- 


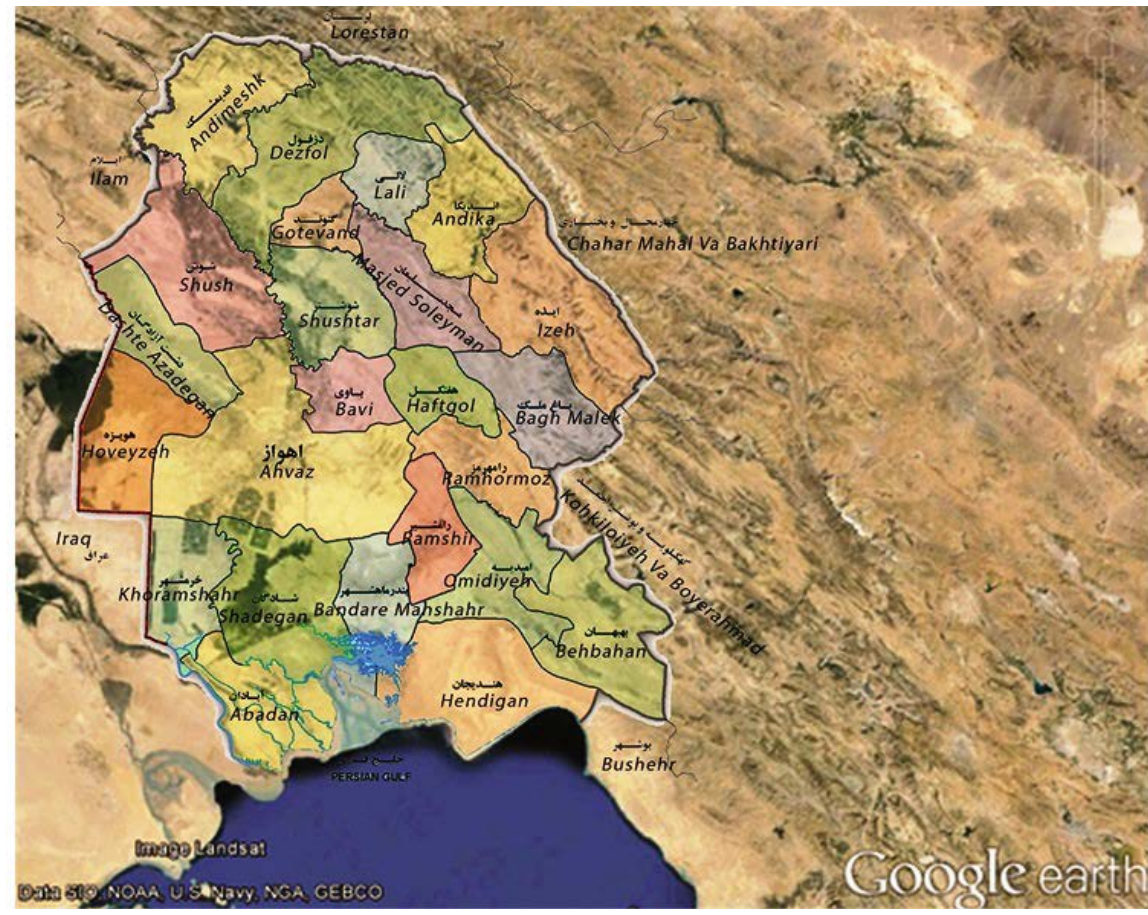

Figure 1. Geographical location of the Gotvand area, Khuzestan province, Iran.

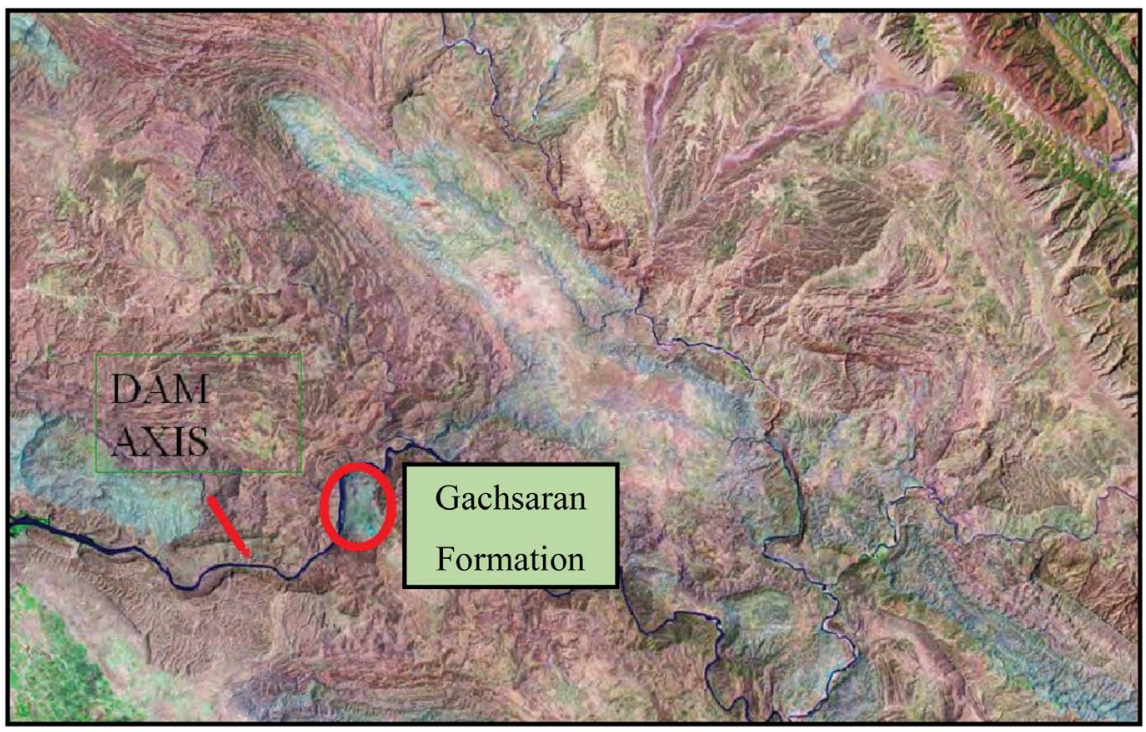

Figure 2. Satellite image of Gachsaran Formation in study area.

tion. Gachsaran Formation is without a complete surface cutting, due to its plastic properties resulting from the presence of thick layers of salt and marl, which deforms the layers and disintegrates them. The age of Gachsaran formation in Dezful Embayment is lower Miocene [12].

\section{Stratigraphy of Gachsaran Formation}

To During geological time, simultaneously with the event of tectonic processes and the decrease of the depth of existing basins, different evaporative formations 

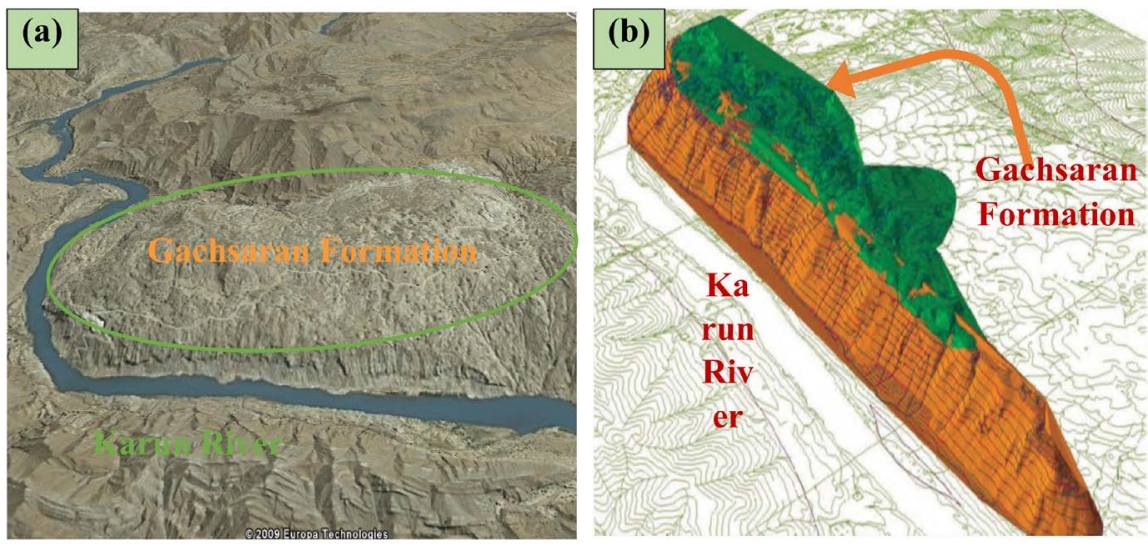

Figure 3. Satellite image of the geochemical section of the Gachsaran Formation; (a) Falling pits that appear on the surface of the Gachsaran Formation as a smallpox; (b) Gachsaran Formation is shown as an anticline along the Karun River.

have been formed in different parts of Iran. These evaporative depositions can be classified into three groups: Precambrian (Hormuz series), Jurassic (Kangan and Heath) and Tertiary (Qom, Upper Red and Gachsaran formations) [13]. Gachsaran Formation in the Zagros sedimentary basin has expanded in vast areas from northeastern Syria to southwest of Iran. In the phanerozoic sedimentary stratigraphy column of the Zagros basin, there are many evapotranspirational deposits which the Hormoz salt is located at the beginning of this column and the Gachsaran Formation (Lower Miocene) is located in the upper part of this column and forms widespread evaporation units. This formation, the name of which is taken from Gachsaran oil field, is divided into seven sections in the pattern section in Khuzestan [14]. These sections include:

Section 1: The thickness is 39 meters and it is called Cap Rock. This part consists of a period of thick layers of anhydrite with thin lime layers and sometimes with bitumen shale. This section is conformity on Asmari Formation.

Section 2: The thickness is $113.5 \mathrm{~m}$ and includes a thick layer of salt, in which layers of anhydrite and thin layer of lime are seen. Due to the tectonic stimulation, this section has some inconsistent folds.

Section 3: The thickness is 225 meters and consists of two parts. The lower half is of the anhydrite and sub-salt, but in the upper half, a period of anhydrite and thin layers of lime and marl can be seen.

Section 4: Its thickness is $834 \mathrm{~m}$ and consists of salt layers, which are accompanied by marl and gray lime or anhydrite forming part of this section.

Section 5: The thickness is 308 meters, in which the periodicity of anhydrite is observed with red and gray marls.

Section 6: The thickness is 278 meters. At the first $103 \mathrm{~m}$, anhydrite with red marl and lime exist, the middle part consists of salt and anhydrite, and the upper part is $61 \mathrm{~m}$ from anhydrite with red-gray colored marls.

Section 7: This section is conformity with the Mishan Formation, which is anhydrite and gray marl and lime with a total thickness of 137 meters. 


\section{Studying Method}

Strontium Field and laboratory methods have been used for this research. In the field part, while surveying the area and examining the soluble sediments on the surface of the earth, 100 thin sections of samples of SA1, SA4, SA5, SA10, SA12, SA16 borehole cores were prepared and were investigated and their petrography was studied in order to investigate the structure and texture of the evaporative crystals of Gachsaran Formation. The petrography column of these cores was also drawn using the Corel Draw software.

Evaporation sequences provide a lot of information about the sedimentary environment, the climate, and the flow stream process [15]. Types of anhydrite and its texture show evidence of salinity, depth, temperature, environments, and sea level fluctuations, and these are used to interpret paleoclimatology and ancient sedimentary environments [16] [17]. According to the petrographic indices, the sedimentary environment is determined and compared with the present environments [18] [19].

In this study, for the interpretation of sequences and petrography columns of cores and the relationship between anhydrite and these sequences, the concepts of a number of researchers and the information of several key papers and publications have been used [20]-[25].

In order to complete the results of petrographic studies and determination of sedimentary environment, 6 samples from the cores were subjected to X-ray analysis (XRD) at the laboratory of Sharif University of Technology. In this analysis, while identifying the crystals, crystalline percentage and phase of formation have been specified.

\section{Discussions}

Evaporation deposits are of great importance in various geological areas, such as the long-standing climate and conditions governing sedimentary environments. In a narrowly bound sea basin, when seawater evaporates under normal conditions, calcium carbonate is the first solid to be separated. Dolomite may be deposited in the presence of calcium carbonate, but there is no evidence of large deposits of dolomite in this way. In fact, the evaporation of sea water in a closed basin cannot create thick carbonate deposits. With evaporation continuation, calcium sulfate is deposited, which depending on temperature and salinity, gypsum or anhydrite may be formed. In the final stage, halite begins to dissolve and precipitates. Therefore, most evaporative deposits consist of calcium carbonate, calcium sulfate and sodium chloride. Potassium and magnesium salts begin to crystallize only when the volume of the evaporative solution is reduced to $1.54 \%$ of its original volume. According to studies in salt accumulation of different ages, the composition of sea water has not changed much since Cambrian time [26]. According to selected samples for study in this research, Gachsaran Formation in the study area consists of anhydrite, gypsum and halite deposits: 


\subsection{Facies and Sedimentary Environments}

In the following before examining the types of anhydrite crystalline materials, first we briefly describe the types of facies of Gachsaran Formation. The investigation of thin sections and X-ray analysis results have led to the identification of Mudstone and Anhydrite facies in lagoon and Sabkha environments in this formation.

\subsubsection{Mudstone}

Mudstone facies are mostly calcareous and do not have non-skeletal grains and may be accompanied by small crystalline anhydrite. Mad stone facies are preserved due to the lack of fossils and fine grains, and its accompaniment with anhydrite, possibly in supratidal and sabkha coastal sub-environments. The lack of fossils is likely to be due to the high degree of salinity and the lack of proper biological conditions for marine organisms (Figure 4) [27].

Also, the presence of marl in gray to dark gray and a little red, and mainly in the rocks with anhydrite and halite, which is associated with the expansion of anhydrite nodules, can be considered as an indicator of shallow coastal environment, indicating the lagoon environment [28].

Such marl and anhydrite frequency has been reported in the later Miocene cycles of Spain [29] and Poland's Euphorbine Basin [30], which have been interpreted in connection with the fall of the sea level and the formation of the third cycle. The frequency of marl and lime in most cases represents short-term fluctuations in the paleoclimate [31].

Tectonic activity, uplift, formation of joint and fracture, play an important role in accelerating the brine movement in the final stage of diagenetic and it seems that the dissolution of layers and anhydritic nodules has been the most important source of formation of large anhydrite crystalline [32]. According to

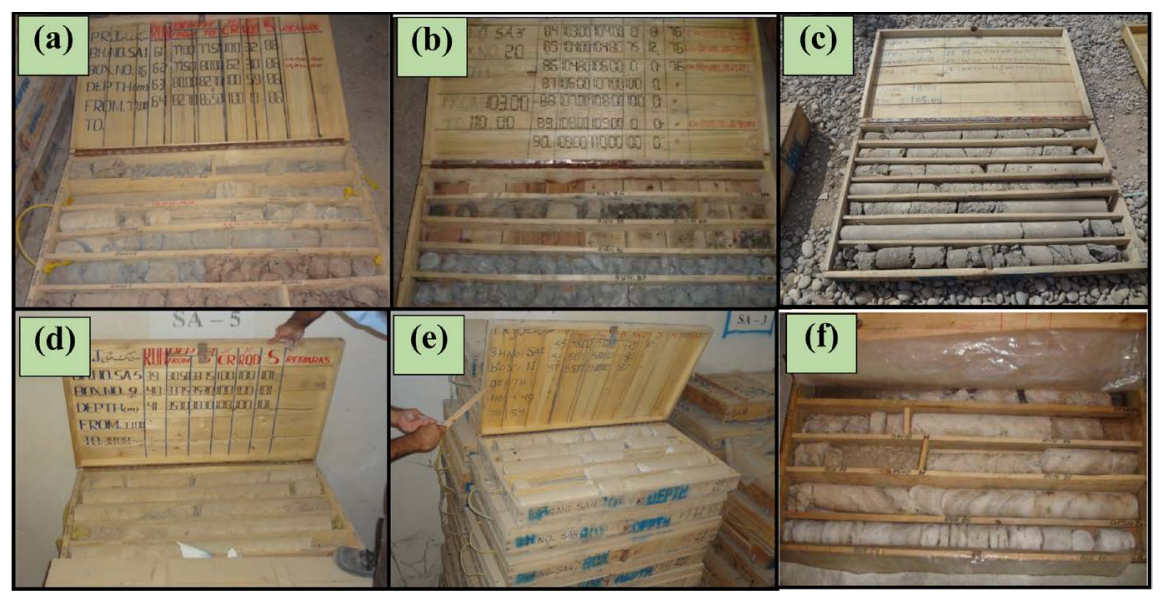

Figure 4. Types of deposits of Gachsaran Formation; (a) Dissolving parts were washed during drilling and the gray and red marls are remained; (b) Dissolved parts were washed during drilling and gray marls remained; (c) Gray Marls of Gachsaran Formation; (d) Full anhydrite cores of anhydrite facies; (e) Complete gypsum cores of anhydrite facies; (f) White salt cores with layering effects. 
Warren [33], the abundance of poorly calcareous mud of non-skeletal grains represents the supertidal or sabkha environment.

\subsubsection{Anhydrite Facies}

The thickness of the sabkha anhydrite facies of the studied area changes from several centimeters to several tens of meters. Anhydrite crystals are fine to coarse crystals. Anhydrite, with the exception of sabkha hot and dry environments, rarely forms in near-surface environments and is usually finely crystallized due to the high rate of nucleation [34]. The most important process for the formation of anhydrite is the loss of water by gypsum during burial at depths of several meters or more. When gypsum is converted to anhydride, water from dehydration reduces the anhydrite strength and thus leads to increased fluidity and high pressure [35]. The abundance of anhydrite in the Gachsaran Formation indicates formation in dry to semiarid climates such as the coastal sabkha of southern Persian Gulf (Figures 4(d)-(f)) [36].

\subsection{Facies Sequence of Gachsaran Formation}

As a result of increasing evaporation in the evaporative basins, the water level in the sedimentary basin decreases while the ionic concentration and water density increase. According to Einsele [37], due to direct deposition of evaporation, closed sea basins, shallow lagoon, Basin due to low water levels in deep parts, deep evaporate basin, Sub evaporative cycles controlled by changes in sea level, Evaporating basins and coastal Sabkha compound are formed. In the formation of these basins, the main processes in the Condensation of brine and Evaporation deposition are similar and the only difference is the change in tectonic environments and their evolution. In the sedimentary basin of Zagros due to the re-activity of Basement faults during Miocene, the conditions for the formation of an enclosed environment have been created and have led to the spread of evaporation. These faults have created the role of a dam for the formation of an evaporative environment. The tectonic subsidence in the basin has been intensified by Deposited evaporates so that the repetition of the precession and retrogradation of sea and the sedimentation of the thick sequence of Gachsaran formation in a shallow coastal environment has been caused [38]. The most important feature of Gachsaran Formation is the cyclic sedimentation and high frequency.

The cyclic deposition is controlled by relative changes in sea level, resulting in glacial, tectonic (subsidence) and sediment processes [39]. Through lower Miocene, the performance of glacial processes in the southern hemisphere has been extensively influenced by changes in sea level. One of the results of the draw down in sea water level is the formation of lagoon-sabkha cycles with frequent rotation. Short-term changes in seawater levels in areas with low topographic differences lead to the formation of these low-thickness (multi-meter) cycles with a large lateral expansion. Gachsaran Formation is formed in the Zagros Foreland Basin. The foreland basins located in front of the orogenic belt, causing 
subsidence on the shell [40]. It seems that the Subsidence in Dezful embayment (in the Zagros Foreland Basin) at the late Oligocene has intensified with the evaporation deposition of the Gachsaran Formation. Therefore short-term shrinkage of the shallow sea, the sedimentation of sediments with plastic properties and continuous subsidence of basin, has provided conditions for the formation of high-frequency cycles. Then because of precession Marl Sea the lagoon environments is formed. Further, increased evaporation has led to the formation of a retrogradation phase which resulted in the development of a sabkha environment in which Anhydrite and Gypsum have been laid out [41]. The results of field studies and X-ray analysis (XRD) confirm this sedimentary environment (Table 1 and Figure 5). This kind of cyclic sediment has been reported in many of the ancient evaporation such as the Arabian Formation to the Upper Jurassic and also the present time on the southern coast of the Persian Gulf [42]. Also deposits of Fat'ha Formation in Iraq have been laid out in a similar sedimentary environment with the Gachsaran Formation [43].

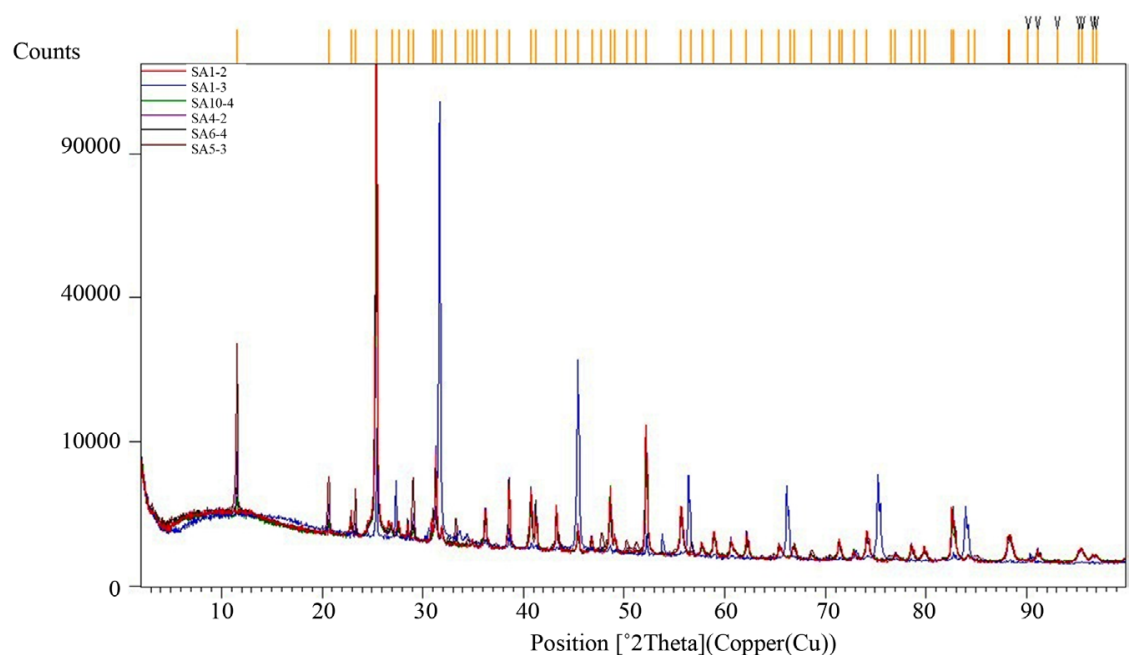

Figure 5. XRD graph of 6 samples from the cores of Gachsaran Formation.

Table 1. Results of XRD analyzes on a number of samples.

\begin{tabular}{|c|c|c|c|c|}
\hline Minor Phase & Major Phase & Depth & Well & Number of sample \\
\hline $\begin{array}{l}\text { Dolomit, Quartz, Manganesium Sulfate, } \\
\text { Silicon Oxide, Sodium Chloride, Corundum }\end{array}$ & Anhydrite & $79.40-79.55$ & SA1 & SA1-2 \\
\hline $\begin{array}{l}\text { Sodium Carbonate, Sodium Sulfate, } \\
\text { Silicon Oxide }\end{array}$ & $\begin{array}{l}\text { Sodium Chloride, } \\
\text { Calcium Sulfate }\end{array}$ & $116.20-116.40$ & SA1 & SA1-3 \\
\hline $\begin{array}{l}\text { Quartz, Manganesium Sulfate, Calcium } \\
\text { Sulfate, Corundum }\end{array}$ & Anhydrite, Gypsum & $50.15-50.40$ & SA4 & SA4-2 \\
\hline Quartz, Sodium Chloride, Corundum & Anhydrite, Gypsum & $38.30-38.60$ & SA5 & SA5-3 \\
\hline $\begin{array}{l}\text { Gypsum, Quartz, Sodium Chloride, } \\
\text { Manganesium Sulfate, Dolomit, Corundum }\end{array}$ & Anhydrite & $50.10-56.30$ & SA10 & SA10-4 \\
\hline $\begin{array}{l}\text { Gypsum, Manganesium Sulfate, Quartz, } \\
\text { Sodium Chloride, Dolomit }\end{array}$ & Anhydrite & $50.10-56.30$ & SA16 & SA16-4 \\
\hline
\end{tabular}




\section{Anhydrite}

Most Anhydrite classification systems have been focus on morphology of masses and Anhydrite crystals [44]. Accordingly the texture and evolution of Gachsaran Formation (including anhydrite, gypsum and halite) have been done based on division Lucia [45] and Warren [46].

\subsection{Anhydrite Structures}

Anhydrite structures in this study have the following types: (Figure 6).

\subsubsection{Massive Anhydrite Structure}

This structure consists of masses in the thickness of a few centimeters to one meter. Massive anhydrite has been composed of various textures such as bladed, parallel, felt, equant and fibrous. Current structures and fossils do not exist in non-porous and uniform Anhydrites. In samples (Figure 6(a)) massive anhydrite is white to cream. In some examples massive Anhydrite with the best forms of nodule is graded and characterized.

\subsubsection{Layered Anhydrite Structure}

In the samples of the cores, various types of bed anhydrite have been formed. The layers of gray or dark brown carbonates and white to gray layers or lamina of sulfate represent this construction. The thickness of the lamina varies from a few millimeters to several centimeters with an irregular or horizontal appearance (Figure 6(b)). Layered anhydrite can include parallel, felt, equant, fibrous and composite textures. Layered anhydrites also formed in two ways: 1) Direct gypsum deposition of saline water and diagenesis of gypsum to anhydrite. 2) The formation of anhydrite from the integration and Continuous Growth of anhydrite nodules in a horizontal direction.

\subsubsection{Chicken-Wire Anhydrite Structure}

Chicken-wire anhydrite structure consists of mosaics of irregular nodules separated from each other by black and thin membranes of mad stone. The diameter of the nodules varies from a few millimeters to several centimeters. Due to the dissolution of the pressure, carbonate deposits can be presented as dark anastomusing branches within the anhydrite. Chicken-wire anhydrite structure often

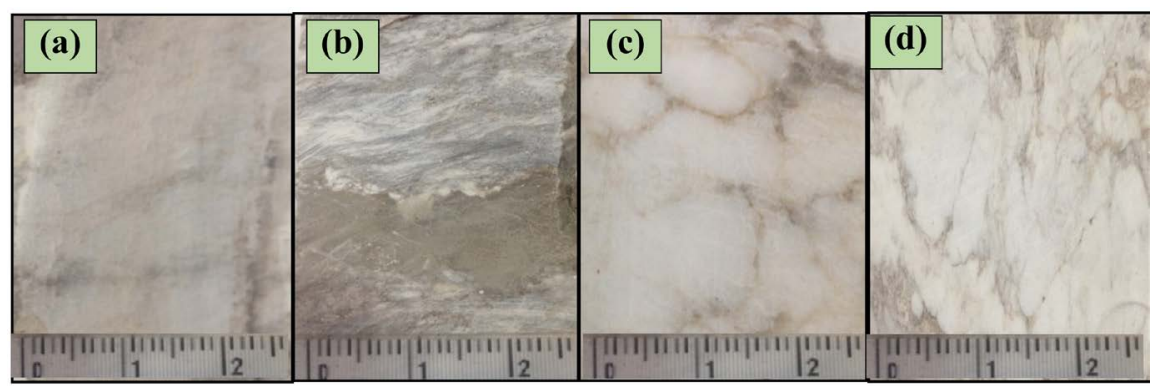

Figure 6. Types of Anhydrite structure in Gachsaran Formation; (a) Massive Anhydrite; (b) Bladed Anhydrite; (c) Chicken-wire anhydrite; (d) Nodular anhydrite. 
has been formed of bladed to fibrous and equant to mosaic textures. In the upper sections of Super taidal or Sabkha with increasing salinity gradually increased the number of nodules and the structure of the Chicken-wire anhydrite have been created (Figure 6(c)).

\subsubsection{Nodular Anhydrite Structure}

In the cores studied, the anhydrite nodules are white to lime to gray. The size of the nodules varies from 0.5 millimeters to several centimeters. Nodules may be completely separated and only be seen or exist in the form of larger nodules composed of smaller nodules. Also some of the nodules are dense and characterized by anhydrite layers. (Figure 6(d)) The nodes are spherical, oval to lens and amorphous forms. In some cuts, the nodules are shown as fibrous textures. Nodular anhydrite is found definitely in Sabkhafacies [47] [48]. Anhydrite nodules are usually formed during the early stages of the diagenesis in the sabkha environments and in small granular sediments such as dolo-mudstone and in some cases also formed as primary gypsum and converted to anhydrate through dehydration [49] [50]. Usually nodular anhydrite is formed in sabkha areas such as the Persian Gulf coast at the same time as sedimentation. Also anhydrite nodules can be formed up to several thousand meters in depth under various environmental conditions such as burial diagenesis [51].

\subsection{Anhydrite Textures}

In this study anhydrite sediments have different types of textures (Figure 7).

\subsubsection{Acicular to Fibrous Texture}

This texture has been characterized by Acicular to Fibrous crystals with parallel-to-non-parallel directional. The size of the fibrous crystals is larger than the Acicular and it shows the elongation or tension. The arrangement of crystals changes from place to place and can be drawn from parallel to non-parallel to mass and layers form. Crystal shapes is needle-like or columnar and ranging in size from $1 \mathrm{~mm}$ to 1 micron. This texture is one of the most commonly used fabrics in massive, bladed, chicken-wire and nodular.

\subsubsection{Sparse and Isolated Crystals}

These crystals are made up of different sizes in the mad stones. The shape of anhydrite crystals is spherical to subspherical, oval, and multilateral. In all instances the size of the crystals is from 0.1 to several millimeters. The dispersed and single crystals may be cut off by fractures and stylolites which are then expected to be formed in the early stages of diagenesis [52]. These evaporation are mostly formed in the upper facies of the intertidal zone up to the beginning of the Sabkha and are present in other evaporating environments such as saline and hyper saline (Figure 7(b)).

\subsubsection{Fibrous Radial Texture}

Fibrous radial texture is characterized by melon and colorful crystals and unique 
conjugation. The size of the crystals is from tens of microns to several millimeters. This texture consists of composite and unique fans so that crystals of stretched fibers are arranged side by side. The crystals are spherical (like a ring) to half-spherical (Figure 7(c) Figure 7(d)). The Fibrous radial texture of anhydrite is much less than equant or acicular anhydrite. This texture is formed mainly in the tidal flat of mad stone facies and is rarely found in lagoon facies.

\subsubsection{Lath Shape (Bladed) Texture}

The Lath shape (bladed) texture is characterized by long crystals of colorful
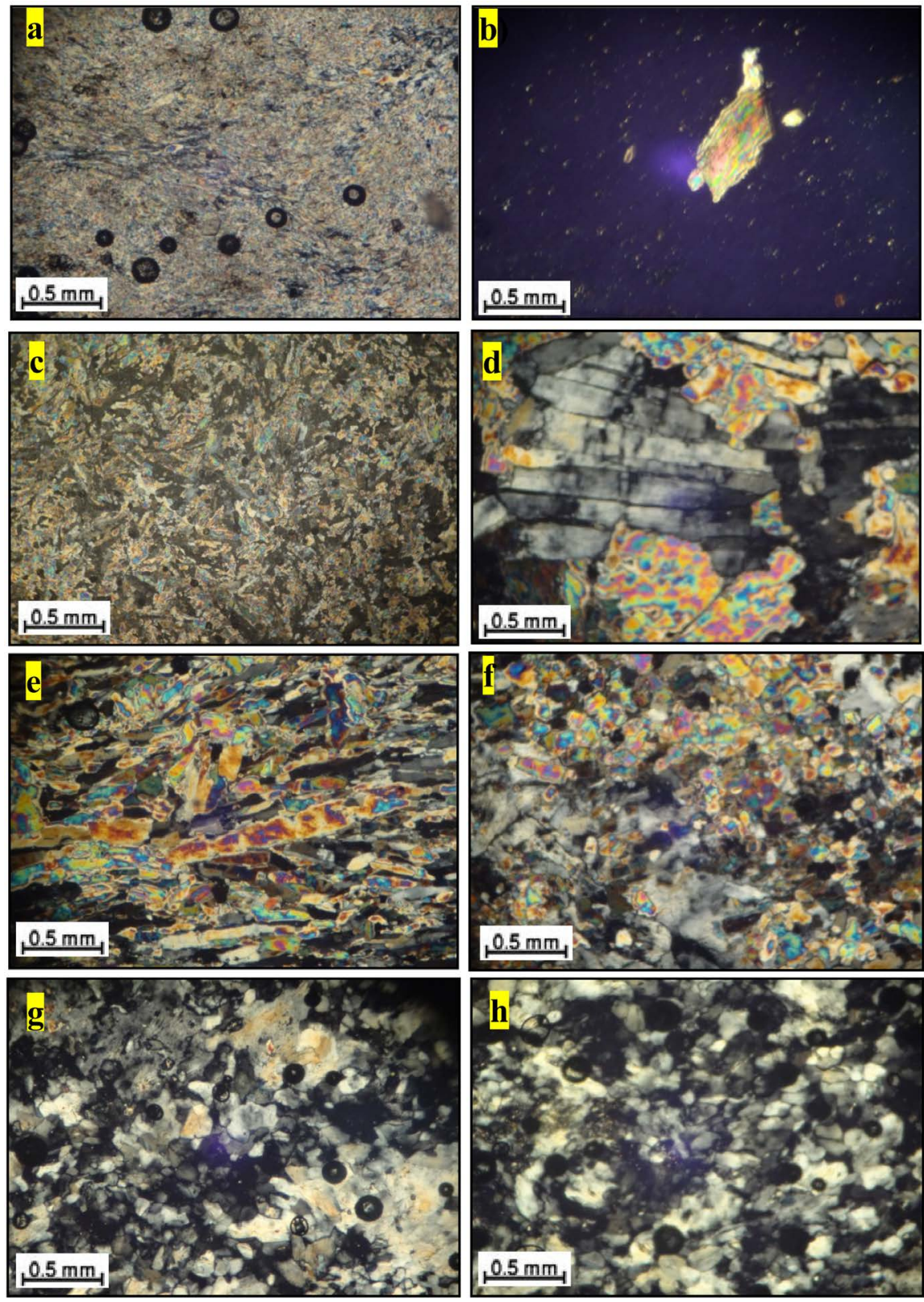

Figure 7. Types of Anhydrite texture in Gachsaran Formation; (a) Acicular to Fibrous texture; (b) Sparse and isolated crystals; (c) Fibrous radial texture; (d) Lath shape (bladed) texture; (e) Composite texture; (f) Gypsum porphyroblasts. 
blades indicating some orientation. Some crystals are still much stretched and tend to split in one direction and parallel to their length. Lath shape anhydrite crystals are Semi-shaped to shapeless and medium-sized (Width: 0.1 to $0.02 \mathrm{~mm}$ and length: $2-2.0 \mathrm{~mm}$ ). This texture is usually observed in lagoon facies (Figure $7(\mathrm{e}))$.

\subsubsection{Composite Texture}

In some instances two or more types of anhydrite texture are observed together and form texture. Sometimes these textures are gradually replaced. This composite texture often includes lagoon facies (Figure 7(f)).

\subsection{Anhydrite Diagenesis Processes}

Anhydrite tends to be formed under sub-surface evaporation or within diagenesis basins [53] [54]. Diagenesis history shows that when anhydrite is coupled with carbonates diagenesis has the most important effects on both lithology. The distinction in the event and occurrences of evaporative diagnoses is generally very difficult because it may be affected by diagenetic environments. Petrography analyzes on evaporation of the Gachsaran Formation show the diagenetic processes including replacement of Anhydrite and rehydration which is shown by the presence of porphyroblastic gypsum during the subsequent freezing. Porphyroblastic gypsum consists of lens-shaped crystals and a large semi-lens with sharp and curved edges. These crystals are individually or hands arranged (Figure 7(g) Figure 7(h)) and large crystals are enclosed by finely Anhydrite crystals. The crystal size varies from 0.2 millimeters to 2 centimeters. Porphyroblasts can be denser and create a Rosette fabric with a diameter of more than 1.5 centimeters. This fabric contains porphyroblastic crystals. This crystalline gypsum is formed secondary and in dehydration of anhydrite [55]. Gypsum porphyroblastic is a valuable index for the stages of pre-diagenesis during diagenesis and after evaporation of diagenesis [56].

\section{Conclusions}

In the evaporite successions formed under the arid climates, such as the Gachsaran Formation in the Gotvand area, Iran, there are unambiguous relationships between the evaporite textures and sea-level fluctuations. Studies on Gachsaran Formation indicate that the most evaporative minerals in this formation are anhydrite, halite and gypsum and the petrography column of the boreholes in this Formation separate layers of anhydrite, gypsum, halite and marlstone have been identified.

Types of anhydrite and its texture show evidence of salinity, depth, temperature, environments, and sea level fluctuations, and these are used to interpret paleoclimatology and ancient sedimentary environments. Seemingly, anhydrite precipitation occurred at two different stages. Early stage anhydrite precipitation from brines and resulted in the formation of anhydrite nodules and beds crystals. As a whole, Anhydrite deposits of Gachsaran Formation include Acicular, 
radial, Lath shape anhydrites and isolated crystals that formed in Sabkha and Lagoon environments.

Diagenesis processes including anhydritization, replacement and recrystallization have been affected calcium sulfate crystals.

Anhydrite with better crystallization energy and more stability than gypsum in the sedimentary environment is better preserved and gypsum dissolves, therefore anhydrite is the dominant phase.

Anhydrite sediments are more than synthetic growth along with sedimentation as well as anhydritization of gypsum during the initial to final diagenesis. They were formed in various diagenetic realms from marine to meteoric and burial. Layered to massive, chicken-wire and nodular anhydrite occurred in very early (near surface) diagenetic stage at the supratidal sub-environment (sabkha).

\section{References}

[1] Warren, J.K. (2006) Evaporates: Sediments, Resources and Hyrocarbons. SpringerVerlag, Berlin, 1035. https://doi.org/10.1007/3-540-32344-9

[2] Schreiber, B.C. and El Tabakh, M. (2000) Deposition and Early Alteration of Evaporates. Sedimentary Geology, 47, 215-238. https://doi.org/10.1046/j.1365-3091.2000.00002.x

[3] Schreiber, B.C. and Helman, M.L. (2005) Criteria for Distinguishing Primary Evaporate Feature from Deformation Features in Sulfate Evaporates. Journal of Sedimentary Research, 75, 525-533. https://doi.org/10.2110/jsr.2005.043

[4] Bugge, T., Ringas, E., Leith, D.A., Mangerud, G., Weiss, H.M. and Leith, T.L. (2002) Upper Permian as a New Play Model on the Mid-Norwegian Continental Shelf: Investigated by Shallow Stratigraphic Drilling. AAPG Bulletin, 86, No. 1.

[5] Warren, J.K. (1989) Evaporate Sedimentology: University of Texas at Austin. 4-62.

[6] Tucker, M.E. (1999) Sabkha Cycles, Stacking and Controls, Gachsaran (Lower Fars/Fata) Formation, Miocen, Mesopotamian Basin, Iraq. Neuesjahrbuch Geologist And Paleontologist Abhand Lung, 124, 45-69.

[7] Rodriguez-Estrella, T. and Pulido-Bosch, A. (2010) Gypsum Karst Evolution in a Diaper: A Case Study (Pinoso, Alicante, Spain). Environmental Earth Sciences, 59, 1057-1063. https://doi.org/10.1007/s12665-009-0097-2

[8] Maximovich, N.G. and Meshcheryakova, O.Y.O. (2009) The Influence of Gypsum Karst on Hydrotechnical Construction in Perm Region.

[9] Torabi-Kaveh, M., Heidari, M., Mohammadi-Behzad, H.R. and Miri, M. (2011) Effect of Dissolved Sodium Chloride Content in Water on the Dissolution of Gypseous Rock (Case Study: Chamshir Dam Reservoir, SW Iran). Australian Journal of Basic and Applied Sciences, 5, 1418-1424.

[10] Torabi-Kaveh, M., Heidari, M., and Miri, M. (2012) Karstic Features in Gypsum of Gachsaran Formation (Case Study: Chamshir Dam Reservoir, SW Iran). Carbonates and Evaporites, 27, 291-297. https://doi.org/10.1007/s13146-012-0090-9

[11] Nabavi, M.H. (1976) A Preface to Iran's Geology. Geology Survey \& Mineral Exploration of Iran, 109.

[12] Motiei, H. (1991) Zagros Stratigraphy. Geology Survey \& Mineral Exploration of Iran, 536.

[13] Rahimpour-Bonab, H. and Kalantarzadeh, Z. (2005) Origin of Secondary Potas 
Deposits; A Case from Miocene Evaporites of NW Central Iran. Journal of Asian Earth Sciences, 25, 157-166.

[14] James, G.A. and Wyned, J.D. (1965) Stratigraphic Nomenclature of Iranian Oil Consortium Agreement Area. American Association of Petroleum Geologists Bulletin, 49, 2182-2245.

[15] Taberner, C., Cendon, D.I., Pueyo, J.J. and Ayora, C. (2000) The Use of Environmental Markers to Distinguish Marine vs. Continental Deposition and to Quantify the Significance of Recycling in Evaporite Basins. Sedimentary Geology, 137, 213-240.

[16] Kendall, A.C. (1984) Evaporites. In: Walker, R.G., Ed., Facies Models: Geoscience Reprint Series 1, Geological Association of Canada, Newfoundland, 259-296.

[17] Tucker, E.G. and Slingerland, R. (1997) Drainage Basin Responses to Climate Change. Water Resources Research, 33, 2031-2047.

[18] Tucker, M.E. and Wright, V.P. (1990) Carbonate Sedimentology. Blackwell Scientific Publications, London, 482. https://doi.org/10.1002/9781444314175

[19] Flugel, E. (2010) Micro Facies Analysis of Carbonate Rocks. Analyses, Interpretation and Application. Springer Verlag, Berlin, 976.

[20] Van Wagoner, J.C., Mitchum, R.M., Campion, K.M. and Rahmanian, V.D. (1990) Siliciclastic Sequence Stratigraphy in Well Logs, Cores and Outcrop: Concepts for High Resolution Correlation of Time and Facies. American Association of Petroleum Geologists Bulletin Method ExplorSer 7, 55.

[21] Emery, D. and Myers, K. (1996) Sequence Stratigraphy. Blackwell Scientific Publications, Oxford, 297. https://doi.org/10.1002/9781444313710

[22] Miall, A.D. (1999) Principles of Basin Analysis. 3rd Edition, Springer-Verlag, Berlin, 616.

[23] Catuneanu, O. (2006) Principles of Sequence Stratigraphy. Elsevier, Amsterdam, 375.

[24] Zamannejad, A., Jahani, D., Lotfpour, M. and Movahed, B. (2013) Mixed Evaporite/Carbonate Characteristics of the Triassic Kangan Formation, Offshore Area, Persian Gulf. Revista Mexicana de Ciencias Geológicas, 30, 540-551.

[25] Aleali, M., Rahimpour-Bonab, H., Moussavi-Harami, R., Jahani, D., et al. (2013) Environmental and Sequence Stratigraphic Implications of Anhydrite Textures: A Case from the Lower Triassic of the Central Persian Gulf. Journal of Asian Earth Sciences, 75, 110-125.

[26] Schreiber, B.C. and Kinsman, D.J.J. (1975) New Observations on the Pleistocene Evaporates of Montallegro, Sicily and a Modern Analog. Journal of Sedimentary Petrology, 45, 469-479.

[27] Alsharhan, A. and Kendall, C.G.C. (2011) Introduction to Quaternary Carbonate and Evaporate Sedimentary Facies and Their Ancient Analogues. International Association of Sedimentologists, 43, 1-10.

[28] Kendall, A.C. and Harwood, G.M. (1996) Marine Evaporates, Arid Shorelines and Basins. In: Reading, H.G., Ed., Sedimentary Environments, Facies and Stratigraphy, Blackwell Scientific Publication, Oxford, 281-324.

[29] Michalzic, D. (1996) Lithofacies, Diagenetic Spectra and Sedimentary Cycles of Messinian Late Miocene-Evaporate in SE Spaine. Sedimentary Geology, 106, 203-222.

[30] Biernacka, J., Borysiuk, K. and Raczynski, P. (2005) Zechstein Ca1 Limestone-Marl Alternations from the North-Sudetic Basin Poland, Depositional or Diagenetic 
Rhythms? Geological Quarterly, 49, 1-14.

[31] Erlick, M. (1996) Sequence Stratigraphy and Platform Evolution of Lower-Middle Devonian Carbonates Eastern Great Basin. Geological Society of America Bulletin, 103, 392-416.

[32] El Tabakh, M., Mory, A., Schreiber, B.C. and Yasin, R. (2004) Anhydrite Cement after Dolomitezation of Shallow Marine Silurian Carbonate of the Gascoyne Platform, Southern Carnnarvon Basin, Western Australia. Sedimentary Geology, 164, 75-87.

[33] Warren, W.J. (2000) Dolomite: Occurrence and Economically Important Association. Earth Science Review, 1-18.

[34] Sonnefeld, P. (1980) Brines \& Evaporates. Academic Press, Orlanda, 613.

[35] Kasprzyk, A. (2005) Diagenetic Alteration Deposits in the Carpathian Fore Deep Basin, Southern Poland: Process and Their Succession. Geological Quaternary, 49, 305-316.

[36] Yechieli, Y. and Wood, W.W. (2002) Hydro Geologic Processes in Saline Systems, Playas, Sabkhas and Saline Lake. Earth Science Reviews, 58, 343-365.

[37] Einsele, G. (2000) Sedimentary Basin, Evolution, Facies, and Sediment Budget. Springer-Verlag, Berlin, Heidelberg, 792.

[38] Bahroudi and Koyi, H.A. (2004) Tectono-Sedimentary Framework of the Gachsaran Formation in the Zagros Foreland Basin. Marine and Petroleum Geology, No. 21, 1295-1310.

[39] Tucker, M.E. (2001) Sedimentary Petrology. 3rd Edition, Blackwell, Oxford, 260.

[40] Mial, A.D. (1997) The Geology of Stratigraphy Sequence. Springer-Verlag, Berlin, 433. https://doi.org/10.1007/978-3-662-03380-7

[41] Kinsman, D.J.J. (1969) Models of Formation, Sedimentary Association and Diagenetic Features of Shallow-Water and Super Tidal Evaporates. American Association of Petroleum Geologists Bulletin, 53, 830-840.

[42] Alsharhan, A.S. and Kendall, C.G.St.C. (2003) Holocene Coastal Carbonates and Evaporates of the Southern Arabian Gulf and Their Ancient Analogues. Earth-Science Reviews, 61, 191-243.

[43] Al-Marsoumi, A.M. (2009) Geology of Miocene Gypsum Deposits in Northern Iraq. Baserah Journal of Science, 27, 17-39.

[44] Meyer, F.O. (2005) Anhydrite Classification According to Structure. http://www.crienterprises.com/Edu Classif Evahtml

[45] Lucia, F.J. (1999) Carbonate Reservoir Characterization. Springer, New York, 226. https://doi.org/10.1007/978-3-662-03985-4

[46] Warren, J.K. (1999) Evaporates: Their Evolution and Economics. Blackwell Scientific, Oxford, 438.

[47] Shearman, D.J. (1978) Evaporates of Coastal Sabkhas. In: Dean, W.E. and Schreiber, B.C., Eds., Marine Evaporates: SEPM Short Course No. 4 Oklahoma City 1978, Society of Economic Paleontologists and Mineralogists, Tulsa, 6-42. https://doi.org/10.2110/scn.78.01.0006

[48] Hardie, L.A. and Eugster, H.P. (1970) The Evolution of Closed-Basin Brines. Mineralogical Society of America, 253-273.

[49] Hovorka, S.D. (1992) Halite Pseudo Morphs after Gypsum in Bedded Anhydrite Due to Gypsum-Anhydrite Relationships. Journal of Sedimentary Petrology, 62, 1098-1111. 
[50] Gundogan, I., Mehmet, O. and Tolga, D. (2005) Sedimentology, Petrography and Diagenesis of Eocene-Oligocene Evaporates: The Tuzhisar Formation, SW Sivas Basin, Turkey. Journal of Asian Earth Sciences, 25, 791-803.

[51] Machel, H.G. (2005) Investigations of Burial Diagenesis in Carbonate Hydrocarbon Reservoir Rocks. Geoscience Canada, 32, 103-128.

[52] Kasprzyk, A. and Orti, F. (1998) Palegeographic and Burial Controls on Anhydrite Genesis: The Badenian Basin in the Carpthian Fore Deep (Southern Poland, Western Ukarine). Sedimentology, 45, 889-907. https://doi.org/10.1046/j.1365-3091.1998.00190.x

[53] Warren, J.K. and Kendall, C.G.St.C. (1985) Comparison of Marine (Sub Aerial) and Salina (Subaqueous) Evaporates: Modern and Ancient. American Association of Petroleum Geologists Bulletin, 69, 1013-1023.

[54] Kasprzyk, A. (2003) Sedimentological and Diagenetic Patterns of Anhydrite Deposits in the Badenian Evaporate Basin of the Carpathian Fore Deep, Southern Poland. Sedimentary Geology, 158, 167-194.

[55] Holliday, D.W. (1970) The Petrology of Secondary Gypsum Rocks: A Review. Journal of Sedimentary Petrology, 40, 734-744. https://doi.org/10.1306/74D7202C-2B21-11D7-8648000102C1865D

[56] Testa, G. and Lugli, S. (2000) Gypsum-Anhydrite Transformations in Messinian Evaporates of Central Tuscany (Italy). Sedimentary Geology, 130, 249-268. 